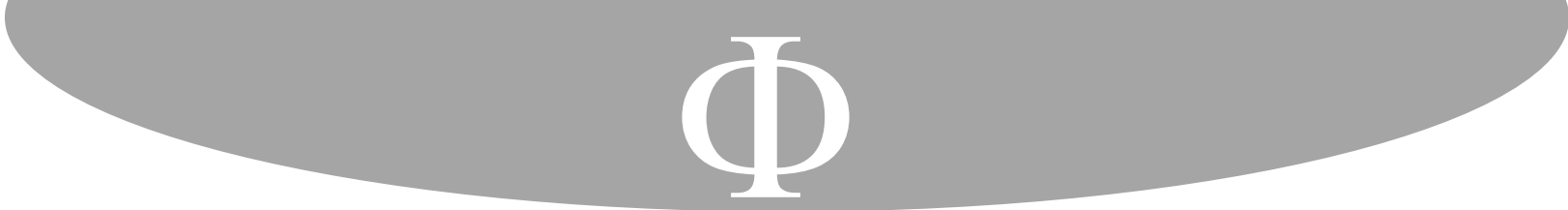

\title{
The general resurrection of the dead in the synoptic gospels*
}

Para citar este artículo: Blanco-Pérez, Carlos. «The general resurrection of the dead in the synoptic gospels». Franciscanum 177, Vol. 64 (2022): 1-29.

\begin{abstract}
The aim of this paper is to analyze the idea of general resurrection of the dead at the end of times in the synoptic Gospels. We intend to clarify whether this concept can be interpreted as a transposition of the parallel belief contained in some intertestamental writings, or if the singularity of the religious experience expressed in the synoptic Gospels establishes an inexorable moment of discontinuity with the previous apocalyptic framework, making it impossible to understand this doctrine on the sole basis of its Jewish precedents. In order to accomplish our goal, we shall first study the general resurrection of the dead in the $\mathrm{Q}$ source, the references to this notion in the gospel of Mark, and its meaning in both Matthew and Luke. We will exclude from our treatment all the topics related with the resurrection of Jesus, and we will be focused on the explicit mentions of the doctrine of the resurrection of the dead as such. Since implicit beliefs are always difficult to assess, especially in the context of eschatological ideas, in which vagueness and absence of a systematic effort of exposition often prevail, we will not allude to other synoptic passages which have been regarded as potential expressions of the doctrine of the resurrection of the dead at the end of times.
\end{abstract}

\section{Keywords}

Resurrection, synoptic, eschatology, apocalypticism, Judaism.

\section{La resurrección general de los muertos en los evangelios sinópticos}

\section{Resumen}

Este artículo tiene como objetivo analizar la idea de la resurrección general de los muertos al final de los tiempos en los Evangelios sinópticos. Pretendemos esclarecer si este concepto puede interpretarse como una transposición de la creencia paralela que aparece en algunos escritos intertestamentarios, o si la singularidad de la experiencia religiosa recogida

\footnotetext{
* This paper is the result of a Visiting Fellowship at Harvard University (2009-2011), funded by Caja Madrid scholarship, and the following study of the philosophical and theological dimensions of Jewish eschatology.

* Doctor en filosofía, doctor en teología, licenciado en química. Universidad Pontificia Comillas, Madrid (España). ORCID: https://orcid.org/0000-0002-8161-6178. Contacto: cbperez@comillas.edu.
} 


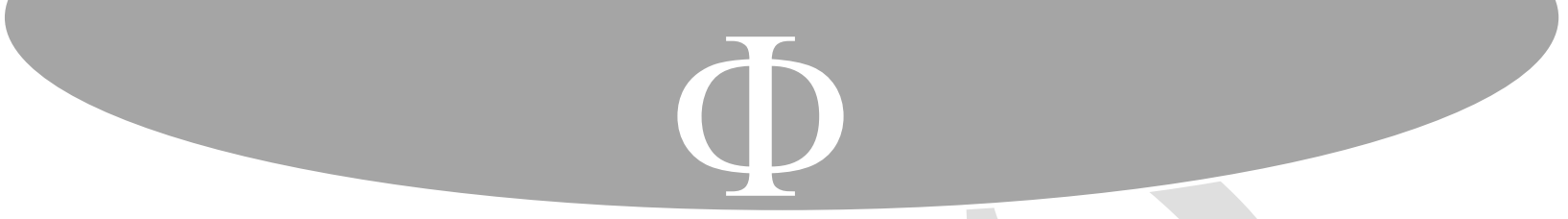

en los sinópticos marca un punto de discontinuidad con el marco apocalíptico previo, lo que imposibilitaría entender esta doctrina sólo desde sus precedentes judíos. Para ello, primero estudiaremos la resurrección general de los muertos en la fuente $\mathrm{Q}$, las referencias a esta noción en Marcos, así como su significado en Mateo y Lucas. Excluiremos de nuestro estudio todos los temas relacionados con la resurrección de Jesús, para centrarnos en las menciones explícitas de la doctrina de la resurrección de los muertos en cuanto tal. Dado que las creencias implícitas siempre son difíciles de evaluar, especialmente en el contexto de las ideas escatológicas, donde la vaguedad y la ausencia de un esfuerzo sistemático suelen prevalecer, no haremos alusión a otros pasajes sinópticos que han sido contemplados como expresiones potenciales de la doctrina de la resurrección de los muertos al final de los tiempos.

Palabras clave

Resurrección, sinóptica, escatología, apocalíptica, judaísmo.

\section{Terminological clarification: the meaning of resurrection}

First, it is necessary to offer a terminological remark ${ }^{1}$ on the different eschatological doctrines $^{2}$ which can be found in late II Temple Judaism ${ }^{3}$. We will be working with the following classification ${ }^{4}$ :

1 References to intertestamental literature will be based on J.H. Charlesworth (ed.), The Old Testament Pseudepigrapha. Biblical quotations will be taken from the New King James Version (1982). References to the Hebrew Bible will be taken from R. Kittel (ed.), Biblia Hebraica Stuttgartensia. References to the Septuagint will be taken from A. Rahlfs, Septuaginta, id est Vetus Testamentum graece iuxta LXX interpretes edidit Alfred Rahlfs. The Greek and Hebrew words are taken from Bible Works 5.0.

${ }^{2}$ B. Rigaux distinguishes two methods of study of Jesus' preaching on the resurrection of the dead: the analysis of those texts which explicitly mention the resurrection of the dead and the examination of the central doctrines of the message of Jesus which "encadrent» these mentions: Dieu l'a Ressucité. Exégése et Théologie Biblique (Gembloux: Duculot, 1973), 23. However, since the second methodology essentially works with a hypothetical statement, we think that it is more convenient to limit our analysis to the explicit, terminological mentions of the general resurrection itself. Given the vagueness of eschatological doctrines in late II Temple Judaism, it would be extremely risky to postulate statements of one of the different possible eschatological doctrines, like resurrection, in those passages in which we only have an affirmation of some sort of existence after death, with no greater specification on the ways in which such a new form of life could be achieved.

${ }^{3}$ For an alternative classification into sixteen categories, cf. J.H. Charlesworth ed., Resurrection: the Origin and Future of a Biblical Doctrine (New York: T and T Clark, 2006), 1-19. However, Charlesworth's classification is excessively detailed. For example, it differentiates between the various types of resurrection on the basis of their Sitz im Leben. We think that it is more didactic to offer a conceptual classification, although it is true that the vagueness with which many intertestamental authors approach the topic of the afterlife seems to suggest that they tend to be concerned with the general statement about some sort of survival after death, not so much with an «analytic» penetration into the implications of their assertions.

${ }^{4}$ See Carlos Alberto Blanco, Why Resurrection? An Introduction to the Belief in the Afterlife in Judaism and Christianity (Eugene: Wipf and Stock Publishers, 2011); Carlos Alberto Blanco, «Hipótesis principales sobre el origen de la idea de resurrección de los muertos en el judaísmo», Estudios bíblicos 4, Vol. 68 (2010): 429 472; Carlos Alberto Blanco, «La escatología apocalíptica y sus posibles influjos exógenos», Cristianesimo nella storia 2, Vol. 32 (2011); Carlos Alberto Blanco, El pensamiento de la apocalíptica judía. Ensayo filosóficoteológico (Madrid: Editorial Trotta, 2013); Carlos Alberto Blanco, «Resurrección, apocalíptica, historia: 


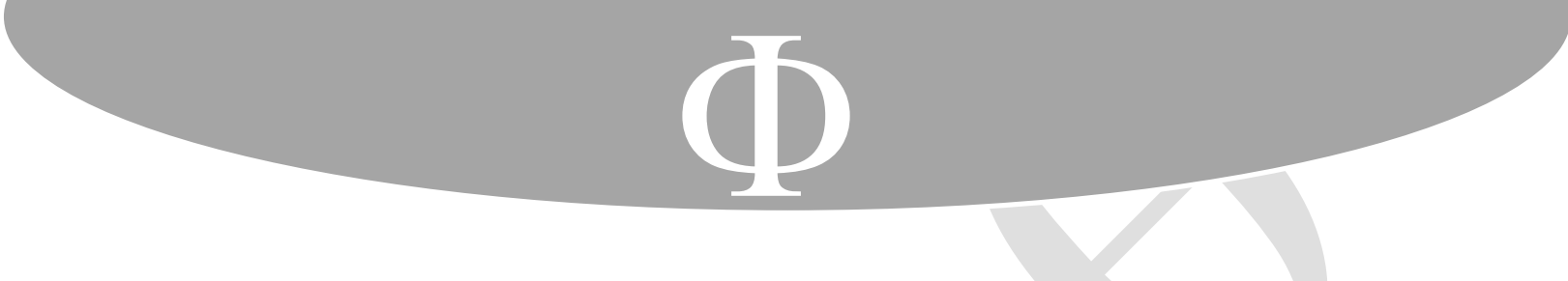

Nevertheless, the pre-eminence of eschatology does not entail an equally binding prevalence of the belief in the resurrection of the dead at the end of times ${ }^{10}$. Eschatology may be focused on the importance of divine judgement, without explicitly mentioning resurrection as the way of accessing such a final judgement. The relevance of the eschatological element in $\mathrm{Q}$ is visible in passages like 3:7-9, 3:16-17, 6:43-45, 10:14, 11:16.29-30.32, 11:48.49, $12: 49.51-53,12: 56,13: 24,13: 29,13: 30,13: 34-35,14: 27,17: 20-21,22: 28.30$. The coexistence of these verses with passages of ethical nature and, within eschatological ideas themselves, the ambivalence of the «eschatological model» makes it difficult to elucidate the kind of eschatology that the author is endorsing ${ }^{11}$. For example, we find, in some cases, a theology which is reminiscent of the so-called «theology of the two ways» ${ }^{12}$, in others, a more apocalyptic tone about the imminence of divine judgement that is, nonetheless, qualified by passages like Q 17:21, in which we are told that the kingdom will not come in a spectacular way).

Kloppenborg attributes to the redacto. Cf. J.S. Kloppenborg, The Formation of $Q$. Trajectories in Ancient Wisdom Collections, 207-208, among other reasons because it uses the title of «Son of Man», but Koester shows that in Q there is no identification between Jesus and the Son of Man. Unlike Matthew -10:32-33- and Mark 8:38; cf. H. Koester, «Apocryphal and Canonical Gospels» 112-114; H. Koester, From Jesus to the Gospels. Interpreting the New Testament in Its Context, 257; H. Schürmann, «Beobachtungen zum Menschensohn-Titel in der Redequelle», in R. Pesch - R. Schnackenburg eds., Jesus und der Menschensohn: für Anton Vögtle (Freisburg im Bresgau: Herder, 1975), 124-197. As Koester remarks, «the original version of Q insists that the ways of the kingdom of God are becoming a reality in the conduct and experience of the disciples because they fall on the voice of an eschatological prophet who announces the presence of the kingdom in the midst», From Jesus to the Gospels. Interpreting the New Testament in Its Context, 261-262. Jesus is, therefore, an eschatological prophet. Kloppenborg himself has admitted the relevance of the eschatological orientation in the original composition of Q. Cf. «The Sayings Gospel Q and the Quest of the Historical Jesus» 337-339, something that leaves room for acknowledging the «diversity of the tradition of Jesus' sayings and for the wide distribution at an early formative stage». H. Koester, From Jesus to the Gospels. Interpreting the New Testament in Its Context, 252, as the fact that sayings present in Q 6:20-46 are also found in the letters of Paul. Cf. H. Koester, Ancient Christian Gospels: their History and Development (London: SCM Press, 1990), 52-55. Even such a hypothetically quintessential example of a sapiential text in the original composition of $Q$ as the inaugural sermon includes explicit references to the similarity of the disciples of Jesus with the prophets of ancient times (cf. Q 6:23), in analogy with the image of a prophet-martyr, like in Daniel and 2 Maccabees.

${ }^{9}$ Cf. J.S. Kloppenborg, The Formation of Q. Trajectories in Ancient Wisdom Collections, 102-170.

${ }^{10}$ For a discussion of the problem of the scope of eschatology in Q, especially in relation with the Easter faith, cf. J.S. Kloppenborg, «'Easter Faith' and the Sayings Gospel Q», Semeia 49 (1990): 71-100; E. Schillebeeckx, Jesus: An Experiment in Christology (New York: Seabury Press, 1979), 409ss. For an alternative view, cf. N.T. Wright, «Resurrection in Q?». In D.G. Horrell - Ch. M. Tuckett eds., Christology, Controversy and Community: New Testament Essays in Honour of David R. Catchpole (Leiden: Brill, 2000), 85-97.

${ }^{11}$ A vivid contradiction occurs between the statements contained in a pericope of the so-called «Logia Apocalypse» that of Q 17:23-24, in which it seems that the coming of the kingdom will take place in spectacular ways, and Q 17:20-21, a passage that explicitly denies this possibility. Could it constitute an attempt at integrating different conceptions about the coming of the kingdom? It is difficult to know.

${ }^{12}$ Examples of the so-called «theology of the two ways» in intertestamental literature can be found in Testament of Aser 1:3-8 and Testament of Judah 20:1-5. Cf. K.M. Woschitz, Parabiblica. Studien zur jüdischen Literatur in der hellenistisch-römischen Epoche (Vienna: LIT Verlag, 2005), 384-388. 


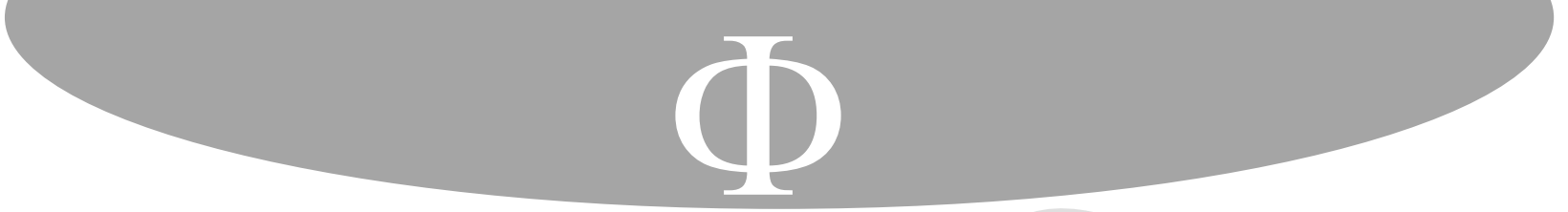

The only explicit mentions of the term «resurrection» in the Q source appear in $\mathrm{Q}$ 7:22 and Q 11:31-32.

a) Q 7:22: «Go report to John what you hear and see: the blind regain their sight and the lame walk around, the skin-diseased are cleansed and the deaf hear, and the dead are raised, and the poor are evangelized» ${ }^{13}$. This text has parallels in Matt 11:2-6 and Luke 7:18$19.22-23^{14}$.

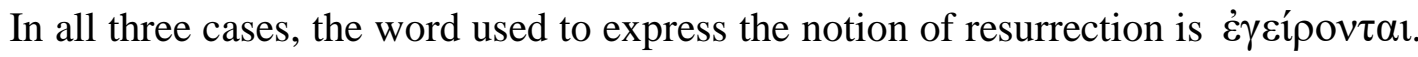
In the Septuagint translation of Dan 12:2, the term was $\alpha v \alpha \sigma \tau \eta \dot{\sigma o v} \tau \alpha$, which also appears

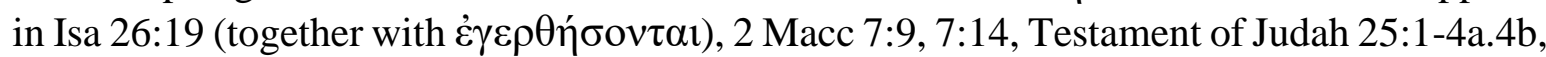
Psalm of Solomon 3:12, Testament of Job 40:4, and in some other Septuagint readings of passages of the Hebrew text which, in principle, lack eschatological connotations, like Ps 1:5

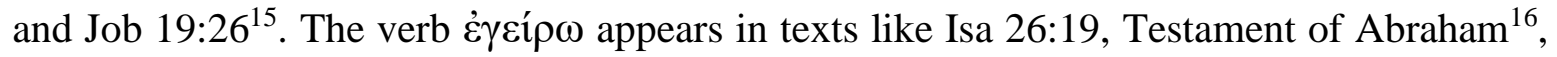
and Testament of Job 4:9. The profusion of terms regarding the action of «raising» and its potential eschatological connotations which can be found in the Hebrew Bible, the Septuagint, and intertestamental writings indicates that there was no systematic effort to unify the lexical field in accordance with a well defined set of theological categories.

There is an inherent lack of accuracy in many texts, so that it is very complicated to clarify whether they are referring to a physical resurrection or to a vague spiritual resurrection of the dead ${ }^{17}$. Passages like Isa 26:19 have been usually included under the label of «collective restoration of the nation», rather than being understood as formal expressions of

\footnotetext{
${ }^{13}$ Cf. J. M. Robinson - P. Hoffmann - J. S. Kloppenborg eds., The Critical Edition of Q: Synopsis Including the Gospels of Matthew and Luke, Mark and Thomas with English, German, and French Translations of $Q$ and Thomas (Minneapolis: Fortress Press, 2000), 7:22.

14 «And when John had heard in prison about the works of Christ, he sent two of his disciples and said to Him, "Are You the Coming One, or do we look for another?" Jesus answered and said to them, Go and tell John the things which you hear and see: The blind see and the lame walk; the lepers are cleansed and the deaf hear; the dead are raised up and the poor have the gospel preached to them. And blessed is he who is not offended because of me» (Matt 11:2-6). «Then the disciples of John reported to him concerning all these things. And John, calling two of his disciples to him, sent them to Jesus, saying, Are You the Coming One, or do we look for another? (...). Jesus answered and said to them, Go and tell John the things you have seen and heard: that the blind see, the lame walk, the lepers are cleansed, the deaf hear, the dead are raised, the poor have the gospel preached to them. And blessed is he who is not offended because of Me» (Luke 7:18-19.22-23).

${ }^{15}$ For analysis of the «suspicions» generated by a hypothetical «pro-eschatological» reading of certain passages of the Hebrew Bible in the Septuagint, cf. J. Schaper, Eschatology in the Greek Psalter (Tübingen: J.C.B. Mohr, 1995), 143ss.; H.C.C. Cavallin, Life after Death: Paul's Argument for the Resurrection of the Dead in 1 Cor 15, vol. I, 103ss.; D.H. Gard, «The concept of the future life according to the Greek translation of the Book of Job», Journal of Biblical Literature 73 (1959): 137-143; R. Tournay, «Relectures bibliques concernants la vie future et l'angélologie», Révue Biblique 69 (1962): 489-495.

16 D.C. Allison, Testament of Abraham (Berlin: Walter de Gruyter: 2003), recension B, chapter 7: $\tau 0 \tau \varepsilon \gamma \alpha \rho \varepsilon \gamma \varepsilon \rho \theta \eta \sigma \varepsilon \tau \alpha 1 \pi \alpha \sigma \alpha \sigma \alpha \rho \xi$. Cf. É. Puech, La Croyance des Essèniens en la Vie Future: Immortalité, Résurrection, Vie Éternelle? Histoire d'une Croyance dans le Judaïsme Ancien, vol. I, 145.

${ }^{17}$ Cf. H.C.C. Cavallin, Life after Death: Paul's Argument for the Resurrection of the Dead in 1 Cor 15, vol. I, 199-201.
} 


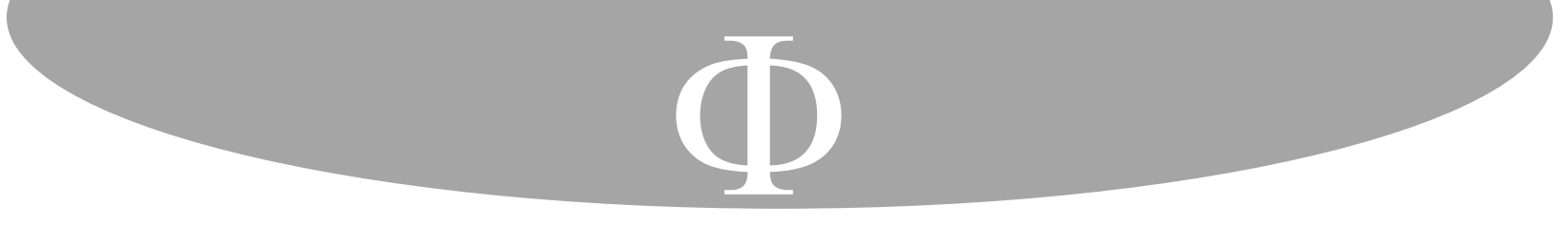

moments in the life of Abraham, who, before dying, initiates an apocalyptic journey in which he receives a series of revelations on the fate of souls and divine judgement. According to the Greek version of this work (the so-called «B version»), generally dated back to $1^{\text {st }}$ century

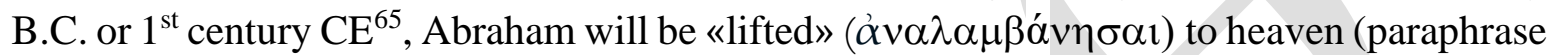
of the exaltation of the righteous man, who shall enjoy divine presence), whereas his body will remain on earth for seven thousand years. After that, «all flesh shall rise» ( $\tau$ ò $\tau \varepsilon \gamma \alpha \rho \dot{\varepsilon} \gamma \varepsilon \rho \theta \eta \dot{\sigma \varepsilon} \tau \alpha \imath \tau \tilde{\alpha} \sigma \alpha \sigma \alpha \dot{\alpha} \xi)$ ). According to É. Puech, the expression «all flesh» refers to the totality of the person ${ }^{66}$, including the corporeal dimension. This may suggest that in some Jewish circles of apocalyptic nature it was accepted that the great biblical patriarchs were, in some way or another, pre-eminent in enjoying divine presence in the afterlife, without having to await the general resurrection of the dead at the end of times ${ }^{67}$. This is what Mark seems to be evoking when incurring in the apparent contradiction of stating, on the one hand, the doctrine of the resurrection of the dead, while at the same time supporting, on the other hand, the idea that Abraham, Isaac, and Jacob are already enjoying divine presence, «life» with $\operatorname{God}^{68}$.

Why does the idea of resurrection that is inferred from this dispute not show a welldefined eschatological orientation in terms of resurrection? Why is the eschatological vigour absent here, while it is present in other passages from this Gospel? Is there an attempt at reconciling a future eschatology with the idea of the spiritual persistence of the person after death? Does Mark have an «eschatological» conception of the afterlife, comparable to the Q source (cf. Q 11:31-32), or, rather, he is committed to the notion of a mere spiritual persistence of the just after death? The answer to this and other questions might lie in the realization that Mark is not trying to bequeath upon his audience a systematic treatment of the topic of resurrection, but he simply wants to defend the existence of life after death. In light of this text, it is possible to recognize two perspectives on the resurrection: the divine one, which is, so to speak, «eternal» (the patriarchs are already alive for God, for He «sees»

without its corporeal dimension? These questions pertain to some of the deepest controversies of Christian eschatology, and their adequate treatment would require a more systematic study in a different paper.

65 Cf. D.C. Allison, Testament of Abraham.

${ }^{66}$ Cf. É. Puech, La Croyance des Essèniens en la Vie Future: Immortalité, Résurrection, Vie Éternelle? Histoire d'une Croyance dans le Judaîsme Ancien, 145.

${ }^{67}$ This idea is, for example, absent in a work which is, in many ways, similar to the Testament of the Twelve Patriarchs: the Testament of Job. According to 4:9, Job will «rise» $(\varepsilon \gamma \varepsilon \rho \theta \eta \sigma \eta)$ in the resurrection $(\alpha \vee \alpha \sigma \tau \alpha \sigma \varepsilon \imath)$, but we are never told that Job enjoys divine presence right after his death. On the composition and reception of the Testament of Job, cf. R. P. Spittler, «The Testament of Job: A History of Research and Interpretation», in M.A. Knibb - P.W. van der Horst eds., Studies on the Testament of Job (Cambridge: Cambridge University Press, 1989), 17-19. This text also seems to incorporate, without any attempt at a systematic integration, the ideas of persistence of the soul and resurrection of the body. Cf. K.M. Woschitz, Parabiblica. Studien zur jüdischen Literatur in der hellenistisch-römischen Epoche, 399-414.

${ }^{68}$ This idea is also connected with the fact, of great importance for apocalypticism, that, according to Gen 5:21 24 (P), Enoch, the seventh patriarch before the Flood, did not die, but was taken to heaven by God, in a similar way as Elijah was not subject to the natural process of death, but was lifted up to heaven in a whirlwind (cf. 2 Kgs 2:11). On the Old Testament references to Enoch, cf. H.S. Kvanvig, The Roots of Apocalyptic. The Mesopotamian Background of the Enoch Figure and of the Son of Man (Neukirchen-Vluyn: Neukirchener Verlag, 1988), 119-126. 


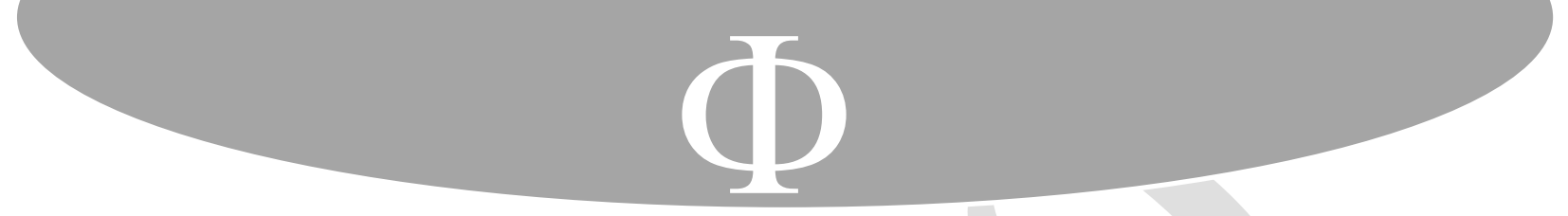

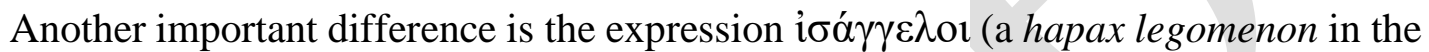
New Testament), which has parallels in Philo of Alexandria (De Sacrificio Abel 1: he applies it to Abraham), 2 Baruch 51:10, and 1 Enoch 15:6. Although, as J.A. Fitzmyer notices, the presence of this expression in Luke shows that this Gospel is «less Semitic» than Mark ${ }^{89}$, we should not forget the relevance of angels in eschatological frames in the Hebrew Bible and several intertestamental writings ${ }^{90}$.

The explicit mentions of the idea of general resurrection of the dead in Luke generate, just as in Mark and Matthew, great confusion regarding the scope of this doctrine in the mind of the evangelist. Luke 14:14 speaks in terms of «the resurrection of the just»: «Then you will be blessed, for they have no means to repay you and so you will be repaid when the

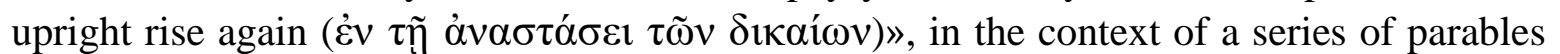
(like the one on the guests and the wedding feast) that Jesus pronounces during his trip to Jerusalem, which are connected with the kingdom of God (cf. Luke 14:15). According to J.A. Fitzmyer, the background to this passage is Dan 12:2 and the conception of the resurrection as a reward for those who have suffered in the name of $\operatorname{God}^{91}$.

Resurrection, at least according to Luke, seems to be restricted to the just people. It is therefore a reward resulting of good ethical behaviour, not just a means so that divine

${ }^{89}$ Cf. J.A. Fitzmyer, The Gospel according to Luke, vol. II, 1305. On the parallels to this expression, cf. also 1QSb 4:25; 4 Macc 16:25 (in which the idea of immortality of the soul prevails). Cf. F. Bovon, Das Evangelium nach Lukas, vol. IV (Zürich: Benziger Verlag, 1989-2009), 119, note 65; cf. J.J. Kilgallen, «The Sadducees and Resurrection from the Dead», Biblica 67 (1976): 487-495.

90 Cf. Isa 63:9, 1QS $4: 22-2$; 1QS 4:24b-25, 1 Enoch 504 , 104:4-6, 2 Baruch 51 :10. The speculations concerning the nature of angels in intertestamental literature are particularly relevant in texts such as 1 Enoch 6-11, 15:6-7, Jubilees 5:1-2, and in Qumran writings like 4Q 180. It is also present in the Damascus Document $2: 16-21$.

${ }^{91}$ Cf. J.A. Fitzmyer, The Gospel according to Luke, vol. II, 1048. Together with the features of the pericope of the discussion with the Sadducees which are reminiscent of both the Testaments of the Twelve Patriarchs and Testament of Abraham, there are other elements that keep resonances of Dan 12:3, in which we are told that «those who are wise shall shine Like the brightness of the firmament, and those who turn many to righteousness Like the stars forever and ever». This «stellar immortality» of the just is also present in texts like 1 Enoch 104:2, Wisdom 3:7, 2 Baruch 51:10, 4 Ezra 7:97, and Book of Biblical Antiquities 33:5. Here, the evangelist would be endorsing a conception rather extended within apocalyptic circles, according to which a series of people (most notably martyrs) will shine like the stars of heaven after their death. But, again, we cannot know how this stellar immortality fits with the doctrine of the resurrection of the dead at the end of times and with the teachings about the kingdom of God. The evangelist may be echoing different intertestamental doctrines, which had become popular by the time of Jesus, but nowhere else in the Gospel we have a clue on how all of them should be integrated into a coherent theological picture. In this sense, it seems reasonable to suppose (based, at least, on its lack of importance in the Q source and its ambiguity in Mark) that the idea of the general resurrection of the dead did not play a central role in the preaching of Jesus. Even if he had accepted it, he might have simply assimilated this notion in the rather vague connotations that it offered in the majority of intertestamental writings in which it appears. As B. Rigaux writes, «Le judaïsme tardif connaît une espérance en la résurrection des morts. La diversité des assertions prouve que la doctrine ne peut être regardée comme centrale dans la pensée religieuxe au temps de Jésus (...). La résurrection reste un objet d'hésitation, de spéculation, d'imagerie apocalyptique. Il est exagéré de soutenir que la foi en la résurrection était de première importance pur les Juifs au temps de Jésus», Dieu l'a Ressucité. Exégése et Théologie Biblique, 15. 
